\title{
Anatomical traits related to stress in high density populations of Typha angustifolia L. (Typhaceae)
}

\author{
F. F. Corrêa ${ }^{a *}$, M. P. Pereira ${ }^{a}$, R. H. Madail ${ }^{b}$, B. R. Santos ${ }^{c}$, S. Barbosac , E. M. Castro ${ }^{a}$ \\ and F. J. Pereira ${ }^{a}$ \\ aPrograma de Pós-graduação em Botânica Aplicada, Departamento de Biologia, Universidade Federal de Lavras - UFLA, \\ Campus Universitário, CEP 37200-000, Lavras, MG, Brazil \\ bInstituto Federal de Educação, Ciência e Tecnologia do Sul de Minas Gerais - IFSULDEMINAS, \\ Campus Poços de Caldas, Avenida Dirce Pereira Rosa, 300, CEP 37713-100, Poços de Caldas, MG, Brazil \\ 'Instituto de Ciências da Natureza, Universidade Federal de Alfenas - UNIFAL, \\ Rua Gabriel Monteiro da Silva, 700, CEP 37130-000, Alfenas, MG, Brazil \\ *e-mail: felipecorrea@dbi.ufla.br
}

Received: June 26, 2015 - Accepted: November 9, 2015 - Distributed: February 28, 2017 (With 3 figures)

\begin{abstract}
Some macrophytes species show a high growth potential, colonizing large areas on aquatic environments. Cattail (Typha angustifolia L.) uncontrolled growth causes several problems to human activities and local biodiversity, but this also may lead to competition and further problems for this species itself. Thus, the objective of this study was to investigate anatomical modifications on T. angustifolia plants from different population densities, once it can help to understand its biology. Roots and leaves were collected from natural populations growing under high and low densities. These plant materials were fixed and submitted to usual plant microtechnique procedures. Slides were observed and photographed under light microscopy and images were analyzed in the UTHSCSA-Imagetool software. The experimental design was completely randomized with two treatments and ten replicates, data were submitted to one-way ANOVA and Scott-Knott test at $\mathrm{p}<0.05$. Leaves from low density populations showed higher stomatal density and index. These modifications on stomatal characteristics were more evident on the leaf abaxial surface. Plants from low density populations showed thicker mesophyll and higher proportion of aerenchymal area. Roots from low density populations showed a higher proportion of the vascular cylinder. Whereas, plants from higher density populations showed greater thickness of the endodermis, exodermis, phloem and root cortex. Higher density populations showed a higher proportion of aerenchymal gaps in the root cortex. Therefore, cattail plants from populations growing under high density population show anatomical traits typical of plants under stress, which promotes the development of less functional anatomical modifications to aquatic environments.
\end{abstract}

Keywords: anatomical plasticity, cattail, macrophytes, plant handling, eutrophication, stress.

\section{Características anatômicas relacionadas ao estresse em altas densidades populacionais de Typha angustifolia L. (Typhaceae)}

\section{Resumo}

Algumas espécies de macrófitas podem apresentar um elevado potencial de crescimento, colonizando extensas áreas de ambientes aquáticos. O crescimento descontrolado da taboa (Typha angustifolia $\mathrm{L}$.) causa problemas para a biodiversidade local e para atividades antrópicas, isso também pode levar à competição e problemas para a própria espécie. Dessa forma, o objetivo desse trabalho foi verificar se ocorrem modificações anatômicas em plantas de Typha angustifolia L. de diferentes densidades populacionais, uma vez que essas podem auxiliar na compreensão da biologia dessa espécie. Raízes e folhas de T. angustifolia foram coletadas de populações naturais com alto e baixo adensamento populacional. Esse material vegetal foi fixado e submetido a procedimentos usuais de microtécnica vegetal. As lâminas foram observadas e fotografadas em microscopia de luz e as imagens analisadas no software UTHSCSA-Imagetool. O delineamento experimental foi inteiramente casualizado com dois tratamentos e dez repetições, os dados foram submetidos à análise de variância e ao teste de Scott-Knott para $p<0,05$. As folhas das populações com baixa densidade demonstraram maior densidade e índice estomáticos. Essas características foram mais evidentes na superfície abaxial em comparação com a superfície adaxial. As plantas de populações com baixo adensamento demonstraram maior espessura do mesofilo e área de aerênquima foliar. As raízes das populações com baixo adensamento demonstraram maior proporção do cilindro vascular. Por outro lado, as plantas de populações com alto adensamento demonstraram maior 
espessura da endoderme, exoderme, floema e do córtex nas raízes. Populações de alto adensamento demonstraram maior proporção de aerênquima no córtex radicular. Portanto, plantas de taboa sob alto adensamento populacional estão sob estresse o qual promove o desenvolvimento de modificações anatômicas menos funcionais para os ambientes aquáticos.

Palavras-chave: plasticidade anatômica, taboa, macrófitas, manejo, eutrofização, estresse.

\section{Introduction}

Macrophytes are a plant group that colonizes water environments. These plants play an important role in water ecosystems, participating in nutrient cycling, organic matter production, eutrophication and pollutant control. Furthermore, they may colonize extensive areas of water bodies and provide shelter and food to animals (Cervi et al., 2009; Pereira et al., 2011).

Macrophytes can have elevated reproductive capacities, being able to achieve intense population growth, which favors the colonization of vast water body areas. This population behavior may damage hydroelectric energy production, river traffic, agricultural irrigation and nautical sports practice (Thomaz, 2002). Cattail population growth, in special, may decrease the size of other macrophyte population, as reported to Cladium jamaicense by $\mathrm{Li}$ et al. (2009) and Eleocharis spp. by Macek et al. (2010). The elevated proliferation capacity of macrophytes may be related to plant genotype, which induce anatomical and external morphology modifications (Pereira et al., 2008; Souza et al., 2009). More competitive macrophytes, for example, exhibit higher leaf production and increased root porosity. These modifications are related to a better use of atmospheric resources and gas diffusion throughout the plant (Insausti et al., 2001; Pierini and Thomaz, 2004).

Anatomical modifications that provide higher competitive capacity may be related to stomata characteristics (Ribeiro et al., 2012), photosynthetic tissue thickness (Boeger et al., 2008; Pengelly et al., 2010), aerenchyma formation (Pereira et al., 2010), root apoplastic barriers (Armstrong et al., 2000; Hameed et al., 2009; Pereira et al., 2011) and vascular tissue characteristics (Vasellati et al., 2001). These characteristics may be related to macrophyte survival in stress conditions or higher photosynthetic capacity and nutrient absorption, which enable higher growth capacities in some plants or populations.

Despite the ecologic importance of macrophytes, most of the studies addressing these species are related to plant systematics and flower surveys. This raises the need for works that better elucidate macrophyte biology (Padial et al., 2008). In these species, for example, the population density may influence intraspecific competition, reducing growth rates (Demirezen et al., 2007). A more complete knowledge of macrophyte biology might assist with macrophytes management, contributing to government decisions, expense reduction and environmental preservation (Thomaz, 2002). Cattail (Typha angustifolia L.) is an important macrophyte found throughout Brazilian territory. Cattail is known to exhibit an elevated growth potential, causing problems for management. However, Cattail populations can show different growth capacities, colonizing extensive or reduced areas of environmental water. These growth potentials may be related to anatomical modifications in different T. angustifolia populations.

Therefore, the aim of this work was to evaluate anatomical modifications between $T$. angustifolia plants from populations which exhibit different population densities. This knowledge may help to understand the Cattail biology in natural wetlands and how to cope with the problems related to high density species, harmful to local biodiversity and human activities.

\section{Material and Methods}

Fragments of T. angustifolia L. roots and leaves were collected at the Brazilian southeast region of Alfenas, Minas Gerais State, $21^{\circ} 25^{\prime} 44$ ' S, 45 56' 49” W, from populations growing at natural water bodies. These materials were obtained from populations showing high density (which colonize over $50 \%$ of the water body), as well as low density populations (which colonize less than $50 \%$ of the water body). Root and leaf fragments were collected in healthy condition, showing no necrosis, chlorosis or fungi evidences. Ten samples were obtained from five plants of two populations from high or low densities, totaling ten samples per density type. Root and leaf fragments were fixed immediately after sampling in a solution comprising formaldehyde, acetic acid and ethanol $70 \%$ (F.A.A. ${ }_{70 \%}$ at 1:1:18 ratio) for $72 \mathrm{~h}$ and stored in $70 \%$ ethanol solution until further analysis.

Leaf paradermic sections were obtained using steel blades on both abaxial and adaxial sides. These sections were clarified in sodium hypochlorite solution containing $1 \%$ chlorine, washed in distilled water twice for $10 \mathrm{~min}$, stained with $1 \%$ safranin solution and mounted on microscope slides with 50\% glycerol (Kraus and Arduin, 1997). Transverse sections were performed at the middle region of leaves, as well as in the root maturation zone using a LPC model microtome. These sections were clarified in sodium hypochlorite solution containing $1 \%$ active chlorine, rinsed in distilled water twice for $10 \mathrm{~min}$, stained with aqueous safrablau solution ( $1 \%$ safranin and $0.1 \%$ astra blue at 7:3 ratio) and mounted on microscope slides with 50\% glycerol (Kraus and Arduin, 1997).

The mounted sections were imaged under a Zeiss Microimaging GmbH Scope A1 microscope (Carl Zeiss MicroImaging GmbH, Göttingen, Germany) coupled to a digital camera. The obtained images were analyzed in UTHSCSA-Imagetool and quantitative tissue characteristics were measured in one slide per replicate. Five sections and four fields were considered per slide. Furthermore, stomatal density (number per $\mathrm{mm}^{2}$ ) and stomatal index [(stomatal number/epidermal cells number)*100] were calculated. 
The experiment was carried out in completely randomized design with two treatments (high and low population densities) and 10 replicates. Data were submitted to one-way ANOVA and means compared of by Scott-Knott test at $\mathrm{p}<0.05$ using Sisvar statistical software (Ferreira, 2011). Data was shown as means \pm standard deviation.

\section{Results}

The stomata of T. angustifolia are tetracytic and little or no sinuosity is observed at the anticlinal cell walls of both leaf sides. Furthermore, parallel rolls of epidermal cells are found over the bundle sheath sclerenchymal extensions and show no stomata (Figure 1). In the leaf adaxial side, only stomatal index exhibit significant differences between populations (Table 1). Stomatal index was 3.7\% higher in low density populations (Table 1). On the leaf abaxial side the stomatal density was $5.7 \%$ higher in low density populations (Table 1). In low density populations, stomatal index was $4.1 \%$ higher than in high density populations (Table 1).

T. angustifolia leaves have a one-seriated epidermis in both the abaxial and adaxial sides, followed by three layered palisade parenchyma. Collateral vascular bundles are arranged in parallel rolls in both adaxial and abaxial sides, these bundles show bundle sheath extensions comprising of sclerenchymal fibers, which bind the vascular bundles to the epidermis. Spongy parenchyma is placed between palisade parenchyma of both leaf sides, forming trabeculae,

Table 1. Leaf stomatal characteristics of Typha angustifolia from different natural conditions of population densities.

\begin{tabular}{|c|c|c|}
\hline \multirow{2}{*}{ Condition } & \multicolumn{2}{|c|}{ Adaxial Side } \\
\hline & SD & SI (\%) \\
\hline $\begin{array}{l}\text { High } \\
\text { density }\end{array}$ & $438.78 \pm 95.46 \mathrm{a}$ & $10.01 \pm 1.26 \mathrm{~b}$ \\
\hline $\begin{array}{l}\text { Low } \\
\text { density }\end{array}$ & $450.42 \pm 68.37 \mathrm{a}$ & $10.38 \pm 0.84 \mathrm{a}$ \\
\hline \multirow{2}{*}{ Condition } & \multicolumn{2}{|c|}{ Abaxial Side } \\
\hline & SD & SI (\%) \\
\hline $\begin{array}{l}\text { High } \\
\text { density }\end{array}$ & $433.41 \pm 84.52 b$ & $9.71 \pm 1.08 \mathrm{~b}$ \\
\hline $\begin{array}{l}\text { Low } \\
\text { density }\end{array}$ & $458.16 \pm 79.75 \mathrm{a}$ & $10.11 \pm 0.94 \mathrm{a}$ \\
\hline
\end{tabular}

(SD) - stomatal density; (SI) - stomatal index. Means followed by the same letter do not differ (Scott-Knott, 5\%). Data was shown as means \pm standard deviation.
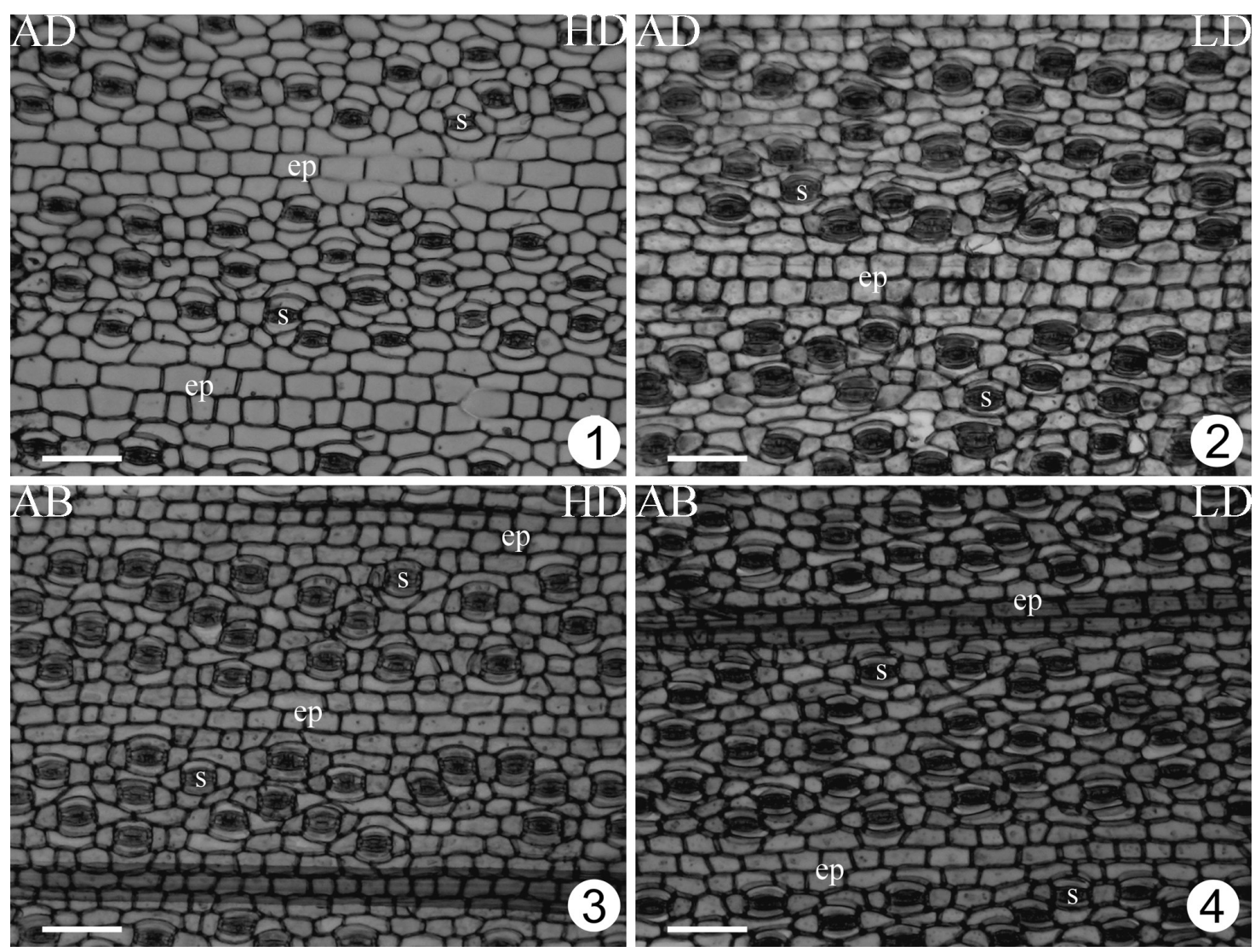

Figure 1. Leaf paradermic sections of Typha angustifolia L. from different natural conditions of population densities. 1 and $2=$ Adaxial side; 3 and $4=$ Abaxial side; 1 and $3=$ high density population; 2 and $4=$ low density population. Bars $=50 \mu \mathrm{m}$. (s) - stomata; (ep) - epidermal cells; (AD) - adaxial side; (AB) - abaxial side; (HD) - high density population; (LD) - low density population. 
which delimit large aerenchymal chambers (Figure 2). The mesophyll thickness was $10.3 \%$ higher in low density than high density populations (Table 2), with similar results being observed for aerenchymal gaps percentage that was $10.9 \%$ higher in low density populations. However, the adaxial epidermis was $4.3 \%$ thicker in plants from high density populations (Table 2).

The roots of Typha angustifolia show one-seriated epidermis with few trichomes. Root cortex is separated into three regions: external cortex (parenchyma cells with few intercellular spaces), middle cortex (large aerenchymal chambers and parenchymal trabeculae) and inner cortex (few layered parenchyma with smaller cells). One-seriated endodermis is visible around the vascular cylinder, followed by one or two layers of pericycle cells (Figure 3). All evaluated characteristics of $T$. angustifolia root anatomy showed statistical differences between populations (Table 3). Exodermis was 5.2\% thicker in plants from high density populations compared to low density populations. Similar results were observed for endodermis and cortex thickness, which exhibit $4.1 \%$ and $13.4 \%$ larger values in high density populations (Table 3 ). Regarding the vascular tissues, phloem was $13.9 \%$ thicker in high density population plants, however, the proportion of the vascular cylinder in roots was higher in low density populations. The aerenchyma proportion in root cortex was $23.8 \%$ higher in plants from high density populations.

Table 2. Leaf cross-section anatomical characteristics of Typha angustifolia from different natural conditions of population densities.

\begin{tabular}{ccccc}
\hline Condition & MT $(\boldsymbol{\mu m})$ & ATA $\left(\mathbf{m m}^{2}\right)$ & EAD $(\boldsymbol{\mu m})$ & EAB $(\boldsymbol{\mu m})$ \\
\hline High density & $2062.87 \pm 672.30 \mathrm{~b}$ & $4.46 \pm 2.02 \mathrm{~b}$ & $17.24 \pm 2.61 \mathrm{a}$ & $17.88 \pm 3.26 \mathrm{a}$ \\
Low density & $2274.83 \pm 459.11 \mathrm{a}$ & $4.94 \pm 1.31 \mathrm{a}$ & $16.54 \pm 2.34 \mathrm{~b}$ & $17.72 \pm 2.85 \mathrm{a}$ \\
\hline
\end{tabular}

(MT) - mesophyll thickness; (ATA) - aerenchyma total area; (EAD) - epidermis thickness from adaxial side; (EAB) - epidermis thickness from abaxial side. Means followed by the same letter do not differ (Scott-Knott, $5 \%$ ). Data was shown as means \pm standard deviation.
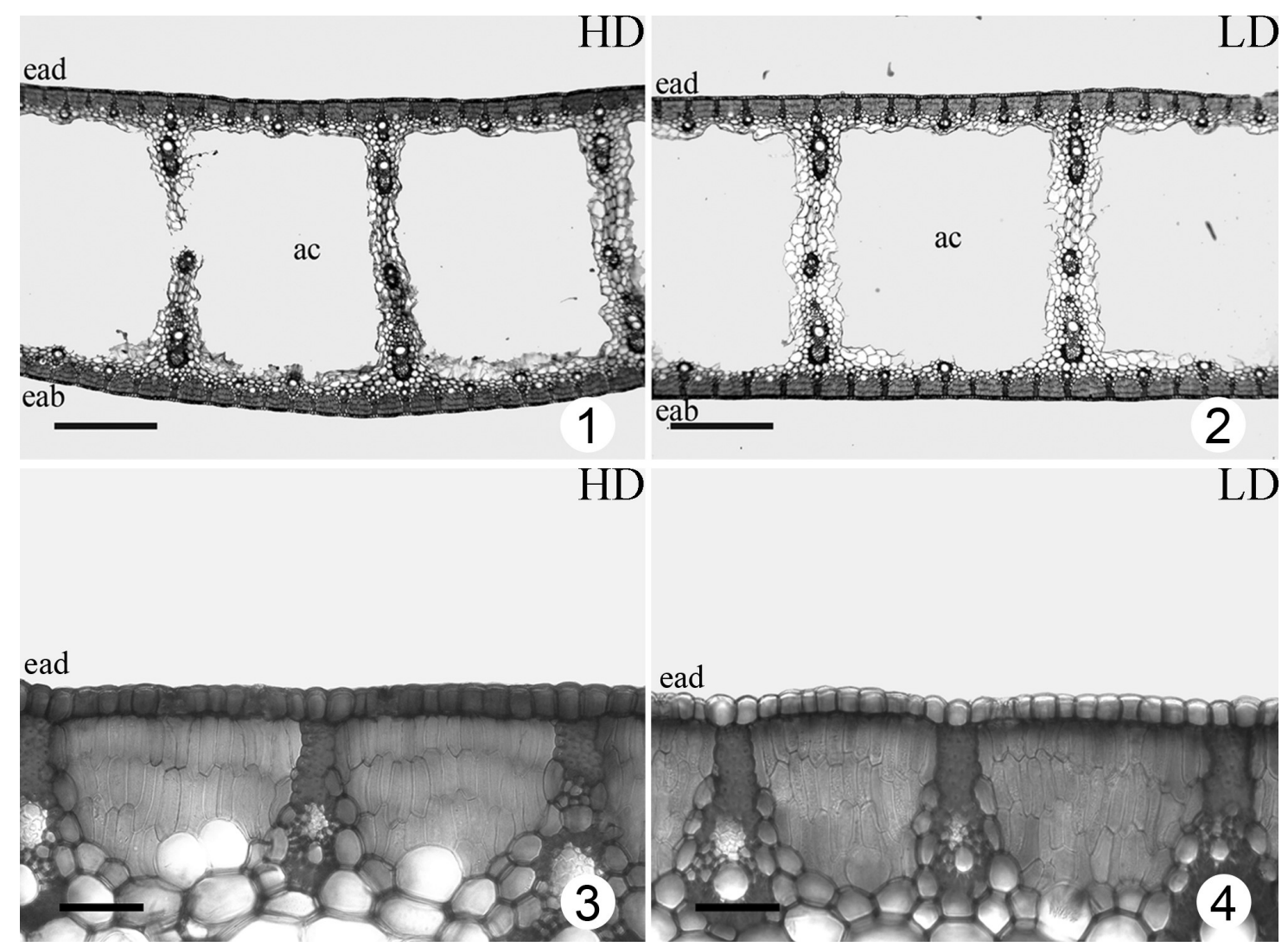

Figure 2. Leaf cross-sections of Typha angustifolia L. from different natural conditions of population densities. $1=$ Leaf cross-section of high density population; 2 = Leaf cross-section of low density population; 3 = Adaxial epidermis details of high density population; 4 = Adaxial epidermis details of low density population. Bars $=500 \mu \mathrm{m}(1$ and 2$)$; Bars $=50 \mu \mathrm{m}$ (3 and 4). (ac) - aerenchymal chamber; (ead) - adaxial epidermis; (eab) - abaxial epidermis; (HD) - high density population; (LD) - low density population. 


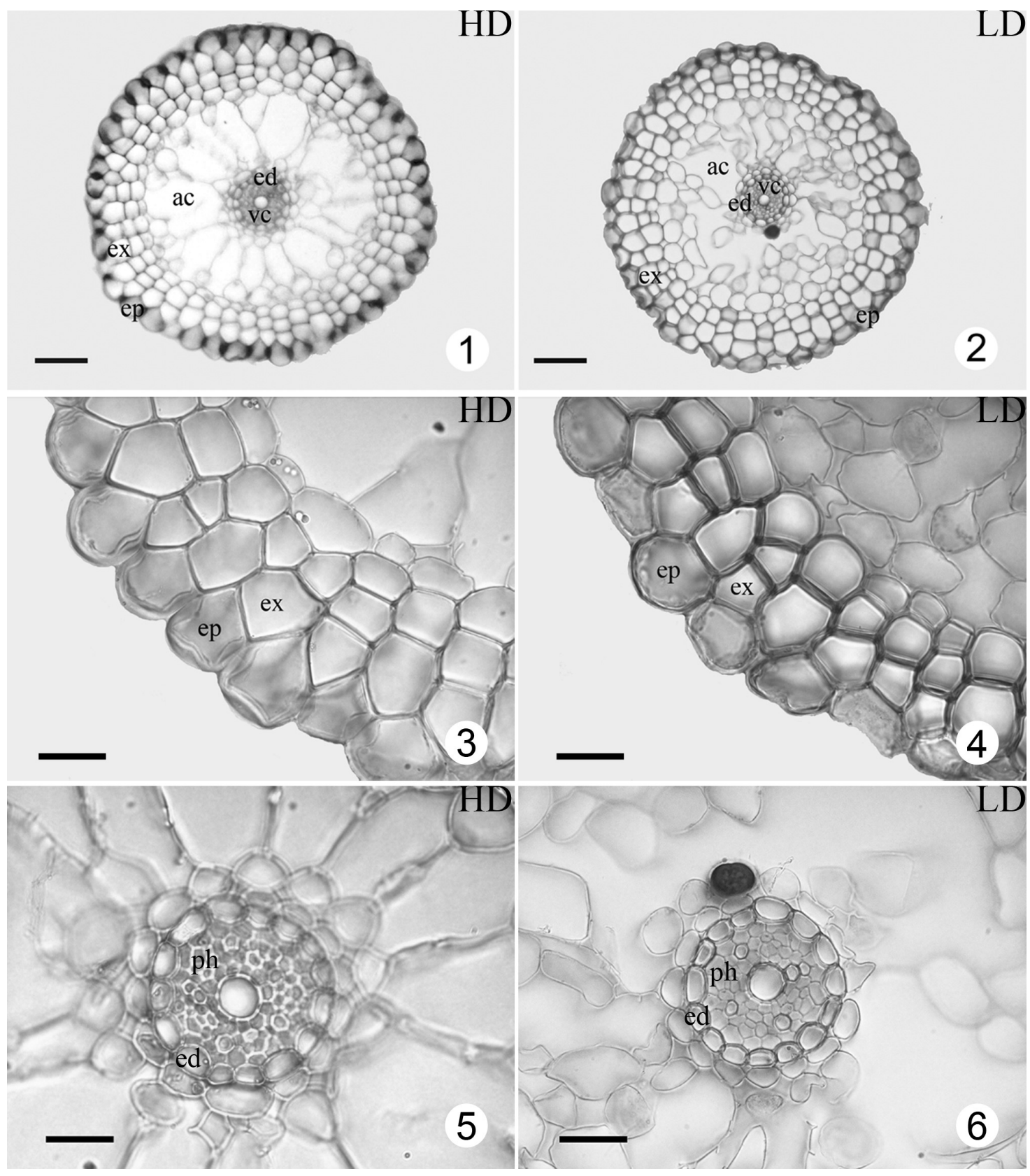

Figure 3. Root cross-sections of Typha angustifolia L. from different natural conditions of population densities. $1=$ Root cross-section of high density population; 2 = Root cross-section of low density population; 3 = Epidermis and exodermis details of high density population; 4 = Epidermis and exodermis details of low density population; $5=$ Endodermis and vascular cylinder details of high density population; 6 = Endodermis and vascular cylinder details of low density population. Bars $=50 \mu \mathrm{m}$ (1 and 2); Bars $=20 \mu \mathrm{m}$ (3, 4, 5 and 6). (ac) - aerenchymal chamber; (ep) - epidermis; (ex) - exodermis; (ed) - endodermis; (vc) - vascular cylinder; (ph) - phloem; (HD) - high density population; (LD) - low density population.

\section{Discussion}

Stomata are modified plant cells related to $\mathrm{CO}_{2}$ uptake and water and $\mathrm{O}_{2}$ release (transpiration). As stomata cells are related to photosynthesis, a higher stomatal density may lead to a higher potential for $\mathrm{CO}_{2}$ uptake and photosynthetic efficiency (Pereira et al., 2011). Genetic variations may lead to different stomatal density, however, species might show differences in stomatal traits due to many environmental factors (Batista et al., 2010; Ribeiro et al., 2012). Therefore, plants growing in high density condition may are under stress, once cattail plants of low density populations show 
Table 3. Root cross-section anatomical characteristics of Typha angustifolia from different natural conditions of population densities.

\begin{tabular}{ccccccc}
\hline Condition & $\begin{array}{c}\text { REX } \\
(\boldsymbol{\mu m})\end{array}$ & $\begin{array}{c}\text { RED } \\
(\boldsymbol{\mu m})\end{array}$ & $\begin{array}{c}\text { RCT } \\
(\boldsymbol{\mu m})\end{array}$ & $\begin{array}{c}\text { PT } \\
(\boldsymbol{\mu m})\end{array}$ & $\begin{array}{c}\text { VCP } \\
(\boldsymbol{\%})\end{array}$ & $\begin{array}{c}\text { APC } \\
(\boldsymbol{\%})\end{array}$ \\
\hline High density & $20.94 \pm 3.04 \mathrm{a}$ & $6.05 \pm 1.23 \mathrm{a}$ & $120.80 \pm 21.42 \mathrm{a}$ & $13.14 \pm 2.40 \mathrm{a}$ & $2.40 \pm 0.38 \mathrm{~b}$ & $26.06 \pm 6.37 \mathrm{a}$ \\
Low density & $19.90 \pm 3.99 \mathrm{~b}$ & $5.81 \pm 1.13 \mathrm{~b}$ & $106.56 \pm 20.95 \mathrm{~b}$ & $11.53 \pm 1.97 \mathrm{~b}$ & $2.58 \pm 0.47 \mathrm{a}$ & $21.18 \pm 9.54 \mathrm{~b}$ \\
\hline
\end{tabular}

(REX) - root exodermis thickness; (RED) - root endodermis thickness; (RCT) - root cortex thickness; (PT) - phloem thickness; (VCP) - vascular cylinder proportion; (APC) - aerenchyma proportion in root cortex. Means followed by the same letter do not differ (Scott-Knott, $5 \%$ ). Data was shown as means \pm standard deviation.

enhanced stomatal characteristics, potentially increasing its photosynthesis.

According Ellison (1987), macrophytes growing under high population density might result in a shading effect, reducing radiation for lower plant parts. Likewise, leaves exposed to lower radiation intensity tend to exhibit lower stomatal density (Pompelli et al., 2010). Therefore, high population density promotes shading stress on plant leaves, reducing stomatal efficiency via structural changes. As a consequence, this may reduce the potential for $\mathrm{CO}_{2}$ uptake and photosynthesis.

Palisade parenchyma is another plant tissue strongly related to photosynthesis. According Boeger et al. (2008), shading reduces the thickness of leaf mesophyll and palisade parenchyma. Pengelly et al. (2010) reported thicker leaves in Flaveria bidentis exposed to higher radiation intensity. However, very little is known about the effects of light intensity on the internal structures of macrophytes. Higher radiation intensity may lead to increased growth and morphological modifications on macrophytes, such as the higher development of fluctuating leaves (Cronin and Lodge, 2003). Thus, the thicker palisade parenchyma of $T$. angustifolia growing under lower population density may be related to a more efficient radiation use. This also supports the fact that the higher population density lead to a shading condition, which may damage the overall photosynthetic capacity through the development of less functional leaves.

The epidermis is one of the most important tissues for plants and is related to plant tolerance for many environmental conditions, such as excessive radiation, pathogens and herbicides (Tuffi Santos et al., 2009; Parent et al., 2008). According to Braccini et al. (2008) and Casa et al. (2007), high density population of plants may lead to a higher incidence of pathogens. Therefore, a thicker epidermis in the leaves of $T$. angustifolia from high density populations could be related to the need for greater protection against an increased pathogen incidence. This would be in-line with the view that high density populations of $T$. angustifolia may be related to stress conditions.

Aerenchyma is a modified parenchymal tissue related to gas storage and is critical for plant survival in aquatic or flooding environments (Insausti et al., 2001; Vasellati et al., 2001; Pereira et al., 2010). As a consequence, plant genotypes more tolerant to flooding conditions often develop higher aerenchyma proportion (Pereira et al., 2008; Souza et al., 2009). Therefore, as low density population showed greater aerenchyma development, it is possible that the harsh condition caused by high density also affects negatively aerenchyma development, promoting a less functional internal structure to cope aquatic environments.

The endodermis and exodermis are important as root apoplastic barriers protecting roots to shoots from soil pollutants and pathogen flux (Hameed et al., 2009; Pereira et al., 2011). According to Armstrong et al. (2000) and Meyer et al. (2011) these structures might also lower water and nutrient uptake from the soil. As high density populations may show increased pathogen development, thicker apoplastic barriers may reduce pathogens flux from roots to shoots of T. angustifolia. Therefore, it could be a tolerance mechanism.

The cortex is related to the root hydraulic conductance because a thinner cortex equates to a shorter distances for water to travel from soil to vascular cylinder (Souza et al., 2009). The thickness of the root cortex can be influenced by both environment and genetic characteristics and a thicker root cortex leads to lower water transport efficiency (Pereira et al., 2008; Hameed et al., 2009; Souza et al., 2009). However, the thicker root cortex observed under high population density might act as a defense mechanism against pathogens but consequently reduce water and nutrient flux, therefore becoming less functional for high density population plants.

Phloem is the principle transport tissue for photosynthesis products and this transport is important for growth capacity and competition (Heo et al., 2014). Therefore, the greater phloem thickness observed in high population density T. angustifolia may have been induced by competition between individuals, promoting root growth to achieve higher nutrient uptake capacity. Aerenchyma proportion in root cortex also may be related to intraspecific competition, since this characteristic has been seen to increase under environmental stress (Vasellati et al., 2001; Coelho et al., 2006; Pereira et al., 2010). Moreover, a higher proportion of root aerenchyma allows greater gas diffusion, mainly oxygen, promoting higher ATP production and growth.

According Souza et al. (2009), the lower proportion of vascular cylinder may also be related to lower hydraulic conductance, supporting the hypothesis that there is a restriction for water and nutrient transport in high density population plants. Thus, we propose that high population density promotes a stress condition in T. angustifolia plants. As preventive evaluation of macrophytes populations is a key point for the proper management of cattail plants 
(Thomaz, 2002), the anatomical differences observed here might assist with the understanding of the different behaviors of cattail populations.

In conclusion, cattail populations from different density conditions show anatomical differences in leaves and roots. Moreover, the data indicates that the T. angustifolia plants of high density population present a less favorable internal structure to aquatic environment, indicating a stressful condition for those populations.

\section{Acknowledgements}

The authors thank CNPq (Conselho Nacional de Desenvolvimento Científico e Tecnológico [National Counsel of Technological and Scientific Development]), CAPESPRODOC (Coordenação de Aperfeiçoamento de Pessoal de Nível Superior [Coordination for the Improvement of Higher Education Personnel]), and FAPEMIG (Fundação de Amparo à Pesquisa do Estado de Minas Gerais [Minas Gerais State Research Foundation]) for funding and research grants awarded to complete the present study.

\section{References}

ARMSTRONG, W., COUSINS, D., ARMSTRONG, J., TURNER, D.W. and BECKETT, P.M., 2000. Oxygen distribution in wetland plant roots and permeability barriers to gas-exchange with the rhizosphere: a microelectrode and modelling study with Phragmites australis. Annals of Botany, vol. 86, no. 3, pp. 687-703. http:// dx.doi.org/10.1006/anbo.2000.1236.

BATISTA, L.A., GUIMARÃES, R.J., PEREIRA, F.J., CARVALHO, G.R. and CASTRO, E.M., 2010. Anatomia foliar e potencial hídrico na tolerância de cultivares de café ao estresse hídrico. Revista Ciência Agronômica, vol. 41, no. 3, pp. 475-481. http:// dx.doi.org/10.1590/S1806-66902010000300022.

BOEGER, M.R.T., GLUZEZAK, R.M., PIL, M.W., GOLDENBERG, R. and MEDRI, M., 2008. Variabilidade morfológica foliar de Miconia sellowiana (DC.) Naudin (Melastomataceae) em diferentes fitofisionomias no Estado do Paraná. Revista Brasileira de Botânica, vol. 31, no. 3, pp. 443-452. http://dx.doi.org/10.1590/ S0100-84042008000300008.

BRACCINI, A.L., SCAPIM, C.A., LANA, M.C., VIDIGAL-FILHO, P.S., ALBRECH, L.P., BARRETO, R.R. and RODOVALHO, M.A., 2008. Produtividade de grãos e qualidade de sementes de café em resposta à densidade populacional. Ceres, vol. 55, no. 6, pp. 489-496.

CASA, R.T., MOREIRA, E.M., BOGO, A. and SANGOI, L., 2007. Incidência de podridões do colmo, grãos ardidos e rendimento de grãos de híbridos de milho submetidos ao aumento na densidade de plantas. Summa Phytopathologica, vol. 33, no. 4, pp. 353-357. http://dx.doi.org/10.1590/S0100-54052007000400006.

CERVI, A.C., BONA, C., MOÇO, M.C.C. and VON LINSINGEN, L., 2009. Macrófitas aquáticas do município de General Carneiro, Paraná, Brasil. Biota Neotropica, vol. 9, no. 3, pp. 215-222. http:// dx.doi.org/10.1590/S1676-06032009000300022.

COELHO, G.T.C.P., SOUZA, I.R.P., CARNEIRO, N.P., SCHAFFERT, R.E., BRANDÃO, R.L., ALVES, V.M.C., PAIVA, L.V. and CARNEIRO, A.A., 2006. Formação de aerênquima em raízes de milho sob estresse de fósforo. Revista Brasileira de Milho e Sorgo, vol. 5, no. 3, pp. 443-449. http://dx.doi. org/10.18512/1980-6477/rbms.v5n3p443-449.

CRONIN, G. and LODGE, D.M., 2003. Effects of light and nutrient availability on the growth, allocation, carbon/nitrogen balance, phenolic chemistry, and resistance to herbivory of two freshwater macrophytes. Oecologia, vol. 137, no. 1, pp. 32-41. http://dx.doi.org/10.1007/s00442-003-1315-3. PMid:12820064.

DEMIREZEN, D., AKSOY, A. and URUÇ, K., 2007. Effect of population density on growth, biomass and nickel accumulation capacity of Lemna gibba (Lemnaceae). Chemosphere, vol. 66, no. 3, pp. 553-557. http://dx.doi.org/10.1016/j.chemosphere.2006.05.045. PMid:16828144.

ELLISON, A.M., 1987. Effects of competition, disturbance and herbivory on Salicornia europaea. Ecology, vol. 68, no. 3, pp. 576-586. http://dx.doi.org/10.2307/1938463.

FERREIRA, D.F., 2011. Sisvar: a computer statistical analysis system. Ciência e Agrotecnologia, vol. 35, no. 6, pp. 1039-1042.

HAMEED, M., ASHRAF, M. and NAZ, N., 2009. Anatomical adaptations to salinity in cogon grass [Imperata cylindrica (L.) Raeuschel] from the Salt Range, Pakistan. Plant and Soil, vol. 322, no. 1-2, pp. 229-238. http://dx.doi.org/10.1007/s11104-009-9911-6.

HEO, J.O., ROSZAK, P., FURUTA, K.M. and HELARIUTTA, Y., 2014. Phloem development: current knowledge and future perspectives. American Journal of Botany, vol. 101, no. 9, pp. 1393-1402. http://dx.doi.org/10.3732/ajb.1400197. PMid:25253700.

INSAUSTI, P., GRIMOLDI, A.A., CHANETON, E.J. and VASELLATI, V., 2001. Flooding induces a suite of adaptive plastic responses in the grass. Paspalum dilatatum. The New Phytologist, vol. 152, no. 2, pp. 291-299. http://dx.doi.org/10.1111/j.0028646X.2001.257_1.X.

KRAUS, J.E. and ARDUIN, M., 1997. Manual básico de métodos em morfologia vegetal. Seropédica: EDUR. 198 p.

LI, S., MENDELSSOHN, I.A., CHEN, H. and OREM, W.H., 2009. Does sulphate enrichment promote the expansion of Typha domingensis (cattail) in the Florida Everglades? Freshwater Biology, vol. 54, no. 9, pp. 1909-1923. http://dx.doi.org/10.1111/j.13652427.2009.02242.x.

MACEK, P., REJMÁNKOVÁ, E. and LEPŠ, J., 2010. Dynamics of Typha domingensis spread in Eleocharis dominated oligotrophic tropical wetlands following nutrient enrichment. Evolutionary Ecology, vol. 24, no. 6, pp. 1505-1519. http://dx.doi.org/10.1007/ s10682-010-9397-y.

MEYER, C.J., PETERSON, C.A. and STEUdLE, E., 2011. Permeability of Iris germanica's multiseriate exodermis to water, $\mathrm{NaCl}$, and ethanol. Journal of Experimental Botany, vol. 62, no. 6, pp. 1911-1926. http://dx.doi.org/10.1093/jxb/erq380. PMid:21131546.

PADIAL, A.A., BINI, L.M. and THOMAZ, S.M., 2008. The study of aquatic macrophytes in Neotropics: a scientometrical view of the main trends and gaps. Brazilian Journal of Biology = Revista Brasileira de Biologia, vol. 68, no. 4, suppl., pp. 1051-1059. http:// dx.doi.org/10.1590/S1519-69842008000500012. PMid:19197475.

PARENT, C., CAPELli, N., BERGER, A., CREVECOEUR, M. and DAT, J.F., 2008. An overview of plant responses to waterlogging. Plant Stress, vol. 2, no. 1, pp. 20-27.

PENGELLY, J.J.L., SIRAULT, X.R.R., TAZOE, Y., EVANS, J.R., FURBANK, R.T. and VON CAEMMERER, S., 2010. Growth of the $\mathrm{C}_{4}$ dicot Flaveria bidentis: photosynthetic acclimation to low 
light through shifts in leaf anatomy and biochemistry. Journal of Experimental Botany, vol. 61, no. 14, pp. 4109-4122. http:// dx.doi.org/10.1093/jxb/erq226. PMid:20693408.

PEREIRA, F.J., CASTRO, E.M., OLIVEIRA, C., PIRES, M.F. and PASQUAL, M., 2011. Mecanismos anatômicos e fisiológicos de plantas de aguapé para a tolerância à contaminação por Arsênio. Planta Daninha, vol. 29, no. 2, pp. 259-267. http://dx.doi. org/10.1590/S0100-83582011000200003.

PEREIRA, F.J., CASTRO, E.M., SOUZA, T.C. and MAGALHÃES, P.C., 2008. Evolução da anatomia radicular do milho 'Saracura' em ciclos de seleção sucessivos. Pesquisa Agropecuária Brasileira, vol. 43, no. 12, pp. 1649-1656. http://dx.doi.org/10.1590/S0100$204 X 2008001200002$.

PEREIRA, F.J., MAGALHÃES, P.C., SOUZA, T.C., CASTRO, E.M. and ALVES, J.D., 2010. Atividade do sistema antioxidante e desenvolvimento de aerênquima em raízes de milho 'Saracura'. Pesquisa Agropecuaria Brasileira, vol. 45, no. 5, pp. 450-456. http://dx.doi.org/10.1590/S0100-204X2010000500003.

PIERINI, A.S. and THOMAZ, S.M., 2004. Adaptações de plantas submersas à absorção de carbono inorgânico. Acta Botanica Brasílica, vol. 18, no. 3, pp. 629-641. http://dx.doi.org/10.1590/ S0102-33062004000300020.

POMPELLI, M.F., MARTINS, S.C.V., CELIN, E.F., VENTRELLA, M.C. and DAMATTA, F.M., 2010. What is the influence of ordinary epidermal cells and stomata on the leaf plasticity of coffee plants grown under full-sun and shady conditions? Brazilian Journal of Biology $=$ Revista Brasileira de Biologia, vol. 70, no. 4, pp.
1083-1088. http://dx.doi.org/10.1590/S1519-69842010000500025. PMid:21180918.

RIBEIRO, M.N.O., CARVALHO, S.P., PEREIRA, F.J. and CASTRO, E.M., 2012. Anatomia foliar de mandioca em função do potencial para tolerância à diferentes condições ambientais. Revista Ciência Agronômica, vol. 43, no. 2, pp. 354-361. http:// dx.doi.org/10.1590/S1806-66902012000200019.

SOUZA, T.C., CASTRO, E.M., PEREIRA, F.J., PARENTONI, S.N. and MAGALHÃES, P.C., 2009. Morpho-anatomical characterization of root in recurrent selection cycles for flood tolerance of maize (Zea mays L.). Plant, Soil and Environment, vol. 55, no. 11, pp. 504-510.

THOMAZ, S.M., 2002. Fatores ecológicos associados à colonização e ao desenvolvimento de macrófitas aquáticas e desafios de manejo. Planta Daninha, vol. 20, no. spe, pp. 21-33. http://dx.doi. org/10.1590/S0100-83582002000400003.

TUFFI SANTOS, L.D., SANT'ANNA-SANTOS, B.F., MEIRA, R.M.S.A., FERREIRA, F.A., TIBURCIO, R.A. and MACHADO, A.F., 2009. Leaf anatomy and morphometry in three eucalypt clones treated with glyphosate. Brazilian Journal of Biology = Revista Brasileira de Biologia, vol. 69, no. 1, pp. 129-136. http:// dx.doi.org/10.1590/S1519-69842009000100016. PMid:19347155.

VASELLATI, V., OESTERHELD, M., MEDAN, D. and LORETI, J., 2001. Effects of flooding and drought on the anatomy of Paspalum dilatatum. Annals of Botany, vol. 88, no. 3, pp. 355360. http://dx.doi.org/10.1006/anbo.2001.1469. 